The Darker Side of Western Modernity 
A book in the series

LATIN AMERICA OTHERWISE Languages, Empires, Nations

Series editors

WALTER D. MigNOLO, Duke University

IRENE SILVERBLATT, Duke University

SONIA SALDíVAR-HULL, University of Texas, San Antonio 


\section{NDO O'}
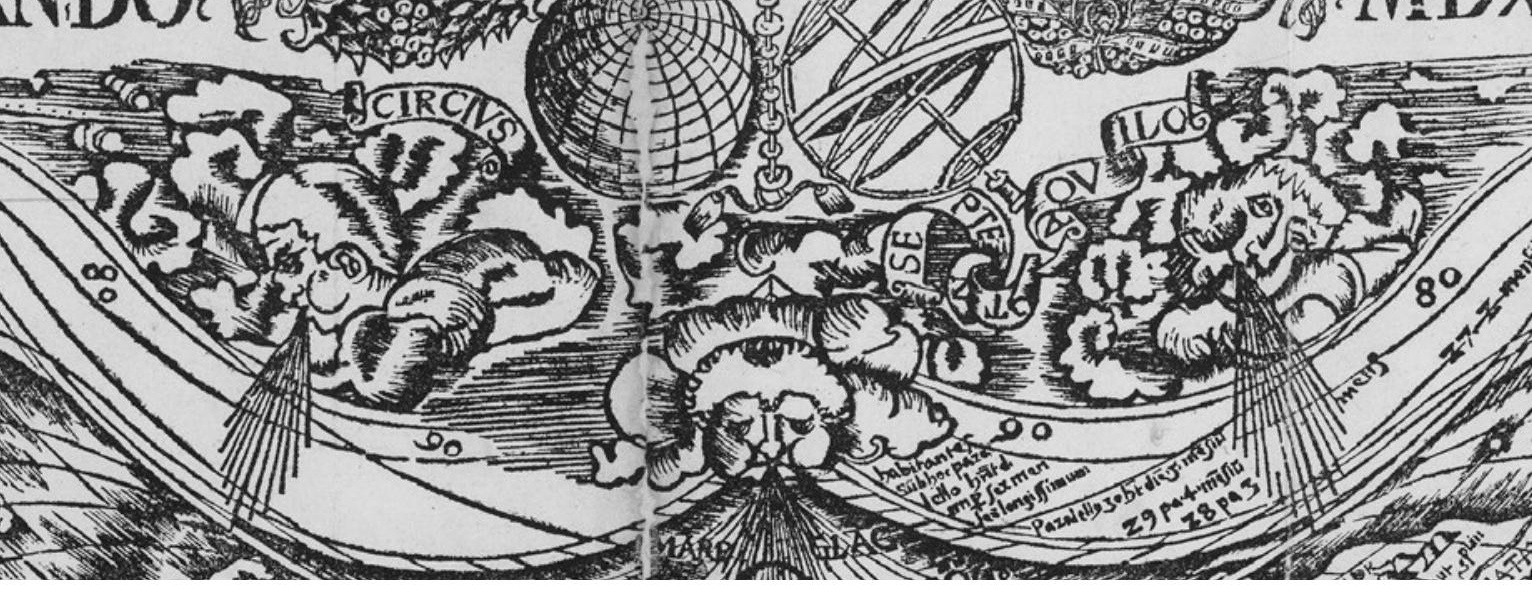

THE DARKER SIDE OF WESTERN MODERNITY

Global Futures, Decolonial Options

Walter D. Mignolo

DUKE UNIVERSITY PRESS Durham \& London 2011

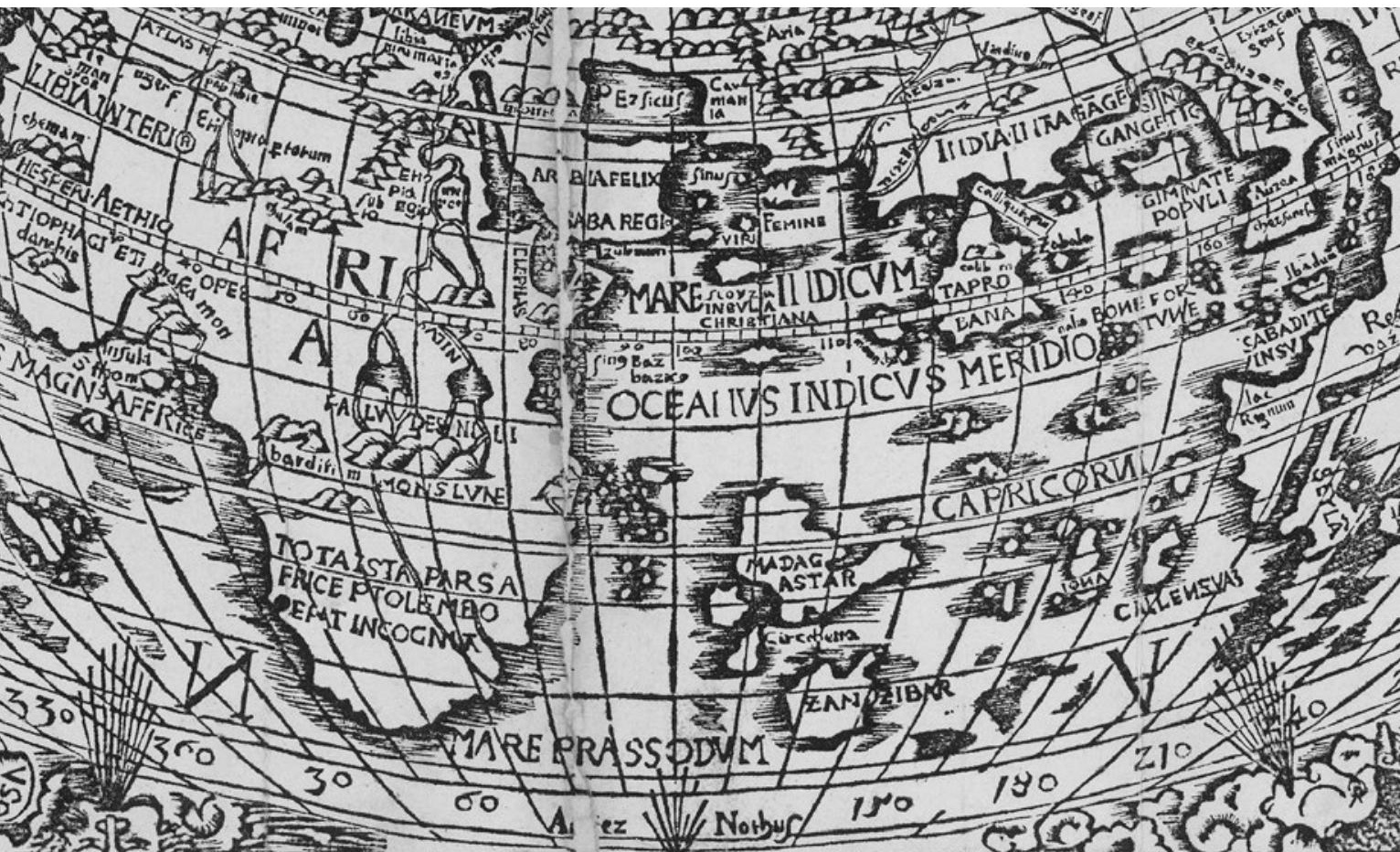


(C) 2011 Duke University Press All rights reserved

Printed in the United States of America on acid-free paper $\infty$

Designed by Jennifer Hill. Typeset in Minion Pro by Achorn International

Library of Congress Cataloging-in-Publication Data

appear on the last printed page of this book. 
Once again, to Andrea and Alexander. Life continues, and so the conversations.

And to Reynolds Smith, for twenty years of conversation and the more than a decade of working on Latin America Otherwise. 
